\title{
DR (MRS) LEAH ROSE SEWE AWITI: AN OBITUARY
}

$\operatorname{Dr}(\mathrm{Mrs})$ Leah Awiti was born on 16 April 1949 in Ugenya, Siaya District and received her primary education in a local school. Thereafter, she joined Rang'ala Girls High School and then Asumbi Girls High School where she did Cambridge School Certificate in 1968. She excelled with distinctions and went on to Nakuru High School for advanced certificate studies and maintained an outstanding academic record which earned her a place at the University of Nairobi in 1971. It was here that she was awarded a B.Sc degree in agriculture in 1974 and distinguished herself in this field of study by being awarded the Gandhi University Award and Faculty of Agriculture Shell Award for her academic excellence. After taking her master's degree in agriculture (1974-1976) and Ph.D. degree in entomology (1976-1980) at the same university, Dr. Awiti served as a lecturer in the Department of Zoology. She embarked on a series of undergraduate and postgraduate lectures in developmental cell biology. Leah had a deep concern for the academic and personal growth of the students.

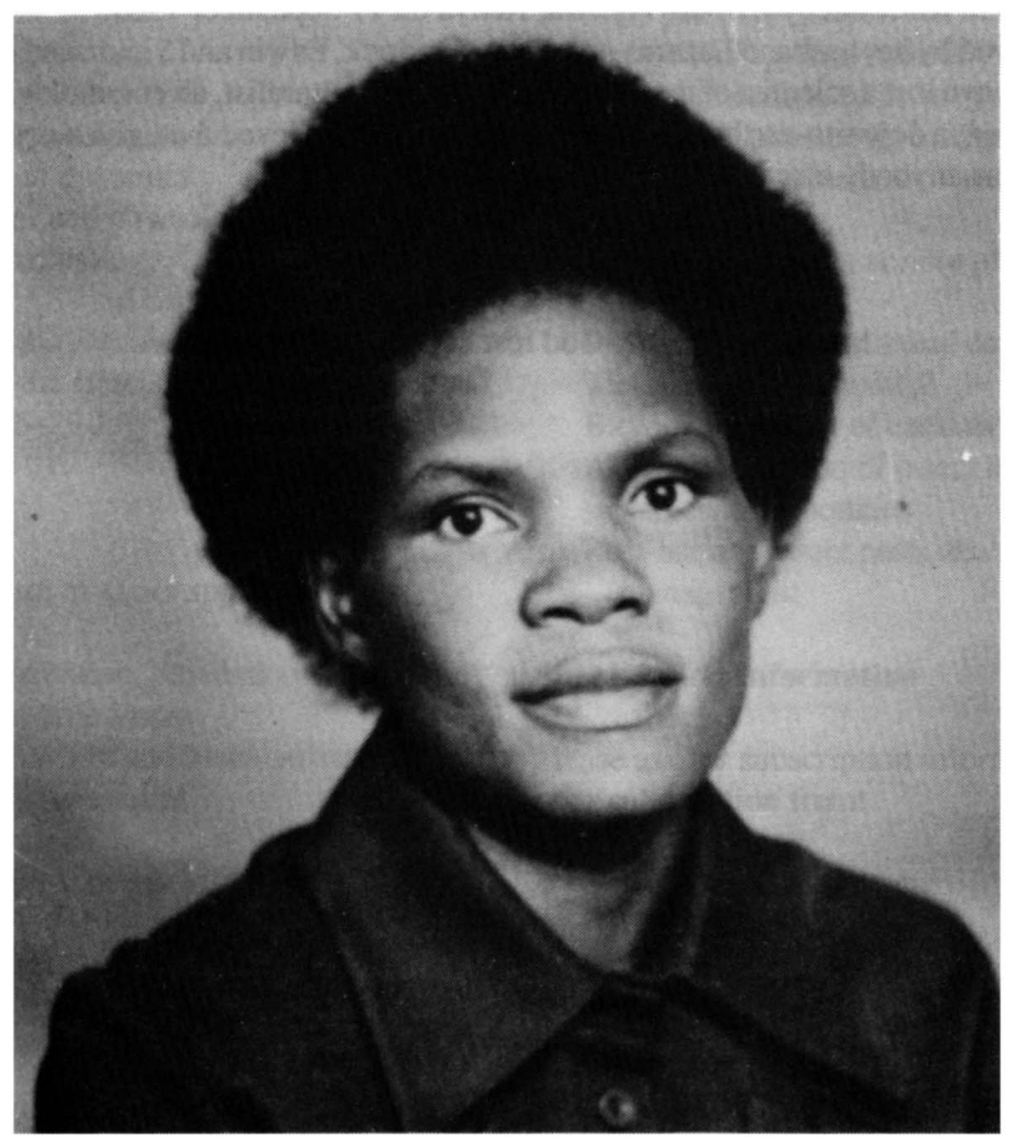

She joined ICIPE on 1 July 1980 as a Postdoctoral Research Fellow in the former Histology and Fine Structure Research Unit and carried out research on the endocrine system of tsetse using electron-microscopy. In 1981 she was awarded a fellowship by the Japanese Society for the Promotion of Science (JSPS) which enabled her to travel to Japan where she spent one year pursuing advanced studies in the area of experimental endocrinology of insects under Professor Toshitaka Hidaka at Kyoto University. Her focus while in Japan was on the silk-producing swallow tail butterfly. She showed that a hormone secreted by the brain was responsible for pupal colour change. Because of her scientific ability and productivity, Leah was promoted to the position 
of Research Scientist on 1 January 1983. It was not long before Leah became a Research Associate in the Unit. Despite her ill health, Leah continued to work effectively at the ICIPE until she was bed-ridden.

Her first ultrastructural article appeared in 1982, describing the secretory cells and functions of the male accessory reproductive glands of the cotton stainer, Dysdercus fasciatus. It was followed by several others, authored alone or in collaboration with other scientists detailing cellular components of tsetse neuroendocrine organs, reproductive tissues and tissue culture, especially of tick embryonic cells. Dr Awiti's research findings have helped to advance the scientific understanding of cellular functions which resulted in the re-designation of the Unit as the Cell Biology Research Unit.

Leah was affiliated to a number of professional organizations including the Society for Invertebrate Reproduction and Association of African Insect Scientists. She will be remembered for her constructive contribution to the work of the Cell Biology Unit, to the ICIPE African Regional Postgraduate Programme in Insect Science (ARPPIS) where she served as a member of the Board of Studies and to the entire ICIPE community.

Those of us who knew Leah will remember her not only for her scientific achievements but especially for her ever-present enthusiasm, patience, warmth, kindness, endurance, bravery and cheerfulness even during the prolonged illness. She was a modest person who took delight in helping others, a conscientious worker, a colleague, and a friend to all who knew her.

$\operatorname{Dr}$ (Mrs) Leah Awiti passed away peacefully at the Nairobi Hospital on 8 September 1989. She was laid to rest at Mawego in Karachuonyo, South Nyanza, Kenya on 17 September 1989.

Leah is survived by her husband Lazarus, three sons Fredrick, Edwin and Simon and one daughter Noel.

In death, we have lost a scientist of dynamic ability: an agriculturalist, an entomologist, a teacher, a cell biologist and indeed, a down-to-earth African lady who strongly believed that, given equal opportunities, a lady was as good as anybody else in scientific endeavours.

May the Almighty God rest her soul in eternal peace 